\title{
Organizational career development versus employees' career needs in Hungary
}

\author{
Brigitta Szabó-Bálint \\ University of Pécs, Faculty of Business and Economics, Pécs, Hungary
}

\begin{abstract}
The aim of the study is to prove that individuals still need the help of their employer to develop their career. Therefore, the paper investigates what kind of career support the employees expect from their employers and compare them to what they actually receive from the organization. The focus is on the career development tools applied by the organizations. Using quantitative research methods via an online survey of 1000 Hungarian employees, this study explores the extent of career development technic usage. It explores the solutions which are preferred by the individuals and also demonstrates the tools used by the organizations. Furthermore, the expected and perceived career support from different actors (managers, HR representatives, mentors, colleagues or external consultant) of the career process is measured and the perceived career opportunities are also evaluated. The most frequently applied tools are special work tasks, project work, networking opportunities, training opportunities and performance appraisal as a basis for career planning, as well as mentoring and coaching. The most often used career management solutions are applied mostly by the most employees; therefore, we can conclude that these are the most popular career interventions. All career management solutions were rated as useful by the respondents on average. However, the efficiency order set by respondents is different from the frequency of use. Career management tools that are evaluated most effective by employees are the following: training opportunities, projects to stimulate learning, networking opportunities, special tasks and promotion, succession planning. On average, respondents were partially informed and career prospects partly meet their expectations. Majority of the workers would expect help in developing their careers, but only few of them actually get support. In conclusion the employers should consider to apply certain career management tools more often as they do or they should involve in it more workers. For more effective cooperation, it would be worth to inform better their employees about career opportunities and give them more career support because they would require it.
\end{abstract}

\section{Keywords}

career, career development, training and development, promotion

\section{Introduction}

In the new career era, where the boundaryless and protean careers are present, the individuals became primary responsible for their career development. It is reasonable if we consider the changes in the form of employment or the expansion of digital labour market where there are more and more freelancers and flexible working conditions (Nica, 2018; Mitea, 2018; Drugău \& Constantin, 2018). Also, for the same reason, employers tend to withdraw from career development process. They are not necessarily partners in managing their employees' careers. They consider it as an unworthy investment. It can be risky because organizations invest energy, time and money in managing the employees' career but they can decide anytime to leave the organization. Furthermore, individuals can have irrelevant expectations from the system which, for this reason, cannot satisfy them. It can cause a problem, too, if the managers are not engaged enough. They will not take it seriously and will not help the employees in their career activities. 
In spite of some disadvantages, it is more beneficial for organizations to deal with career planning and management activities. Numerous benefits can be identified for the employer and also for the employees. It is useful for the organization because it can increase employee motivation, performance and thus the efficiency of the organization. It requires shorter time to resolve the vacancies, helps with succession planning, identifies employees who can become potential leaders later, and provides the opportunity for all employees to identify their career goals. (László, Sipos and Slavić (2018) also argue in their study that the two parties need to co-operate with each other to achieve their aims.)

The aim of the study is to prove that individuals still need the help of their employer to develop their career. Therefore, the paper investigates what kind of career support the employees expect from their employers and compare them what they actually receive from the organization. The focus is on the career development tools applied by the organizations (e.g. training and development opportunities, mentoring, coaching, formal career plan, and career consultation). Using quantitative research methods via an online survey of 1000 Hungarian employees, this study explores the extent of career development technic usage. It explores the solutions which are preferred by the individuals and also demonstrates the tools used by the organizations. Furthermore, the expected and perceived career support from different actors (managers, HR representatives, mentors, colleagues or external consultant) of the career process is measured and the perceived career opportunities are also evaluated.

In conclusion, the study provides an overview about employees' career needs and demonstrates their evaluation about the organizational career development activities.

\section{Organizational career management and its tools}

In this subchapter the content of organizational career management will be clarified and its possible tools will be presented.

\subsection{Organizational career management}

Based on Hall \& Associates (1986) and Leibowitz Farren and Kaye (1986) career management includes personal competencies and organizational actions as well as structures that enable and guide individuals to acquire the necessary skills, knowledge, and attitudes to achieve their personal and career goals and meet the requirements of the work environment. The individual and the organization prepare plans, then refine, implement and monitor them within this process. (Hall \& Associates, 1986; Leibowitz et al. 1986 - in: Creed \& Hood, 2009)

Based on Koncz $(2002,2013)$, organizational career management can be interpreted as the supported, formalized organizational career development of the organization's employees. The target group might be all of the employees or just a specific group. The definition suggests that this is a job-related career activity and it is not necessary to include the whole workforce of the organization.

Gottfredson (2005) believes that organizational career management activities are primarily for the benefit of the organization, and secondly, for the career goals of their employees. In addition, some employers are committed to help their employees to solve their personal, family problems because they understood that these private problems can easily distract their employees from work and undermine good performance. (Gottfredson, 2005) This can be interpreted so that employers have to consider the whole person because privacy can have an impact on work and career decisions.

\subsection{Organizational career management tools}

Employers can use a variety of career management solutions to support their employees' careers, such as career counselling, career planning, various training development opportunities, mentoring, coaching or succession planning (Bernes \& Magnusson, 1996; Baruch, 2008). In the last period we can highlight the following researches which investigated career development interventions:

Baruch \& Peiperl (2000) studied 17 career management practices at 194 UK organizations. The five most commonly used solutions were postings regarding internal job openings, formal education as part of career development, performance appraisal as a basis for career planning, career counselling by direct supervisor and lateral moves to create cross-functional experience.

The results of the 2008-10 Cranet Round were reviewed by Berber \& Slavic (2014). The use of career management techniques shows average low 
frequencies based on the results of the survey. Participation in project teams was applied to the greatest extent by European participants. This was followed by special tasks to stimulate learning/training at work. The third most common solution was involvement in crossorganizational/disciplinary/functional tasks. Mentoring and networking were the following in the ranking.

Lewis \& Arnold (2012) conducted a survey among leaders of commercial organizations in the UK. They found that the most popular solutions were advertising internal job opportunities, involvement, personal development plans and competence development. They found that basic techniques - one of the CM tools category from Baruch \& Peiperl (2000) - are preferred by organizations, because they are simple to use and do not require too much effort on the part of the organization. (Lewis \& Arnold, 2012)

Finally, the research by Madagamage, Perera and Thalgaspitiya (2018) is presented. The authors examined career management practices at listed companies in Sri Lanka. A total of $19 \mathrm{KM}$ tools were tested, 14 were taken from Budhwar \& Baruch (2003) survey. Based on their results, the top five items were: performance appraisal as a basis for career planning, formal development as part of career development, postings regarding internal job openings, special work assignments to career development and formal education as a part of career development.

Summarizing previous research results, the most common career development solutions in the surveyed organizations were solutions such as training-development solutions, internal job opening practices, career consulting, performance appraisal as part of career development, project work and special assignments.

Related to organizational career management practice, it is important to mention that the emergence of new career concepts has also affected the type of career development tools applied. While traditional formal solutions were used earlier, according to Baruch (2003) new innovative interventions have spread with new career concepts. Employers need to take into account the fact that they often have to manage their employees' careers beyond formal organizational boundaries or they need to rethink their relationship with employees. Finally, they also have to consider that employability is more important for workers today (not long-term employability), therefore, those career development solutions should be used which support this new need. (Baruch, 2003)

De Vos \& Cambre (2016) confirms the previous opinion, since the authors see that in recent years, organizations have been using rather supportive and developer KM solutions (according to Clarke (2013), e.g.: coaching, career planning workshops, self-assessment exercises) instead of traditional top-down CM solutions (based on Hamori et al. (2011) e.g.: rigid career ladders, potential survey, promotional routes). Furthermore, Szabó, Slavić and Berber (2019) proved in the case of organizations from Central and Eastern Europe that coaching has positive impact on organizational performance. Namely, they showed that higher level of the usage of coaching for career management in a company is positively related to the level of productivity and negatively related to the level of staff turnover.

\section{Methodology of the research}

1,000 people were interviewed using an online questionnaire in the frame of the empirical research. The respondents are full and part time employees in the private sector. This paper analyses the answers of the following questions: use and usefulness of career management tools, received and expected career support, and assessment of career opportunities and information in the workplace. Data were analyses with SPSS software. Mainly frequency queries, some cross table and correlation analyses have been carried out yet, as the research have been conducted recently, further detailed analyses are planned later.

\subsection{Basic characteristics of the sample}

The sample is representative by age, gender, qualification and residence. The following figure shows basic demographic data. The majority of the respondents are men (64\%), the average age is 42 years. Most employees (75\%) have an intermediate level of education. 


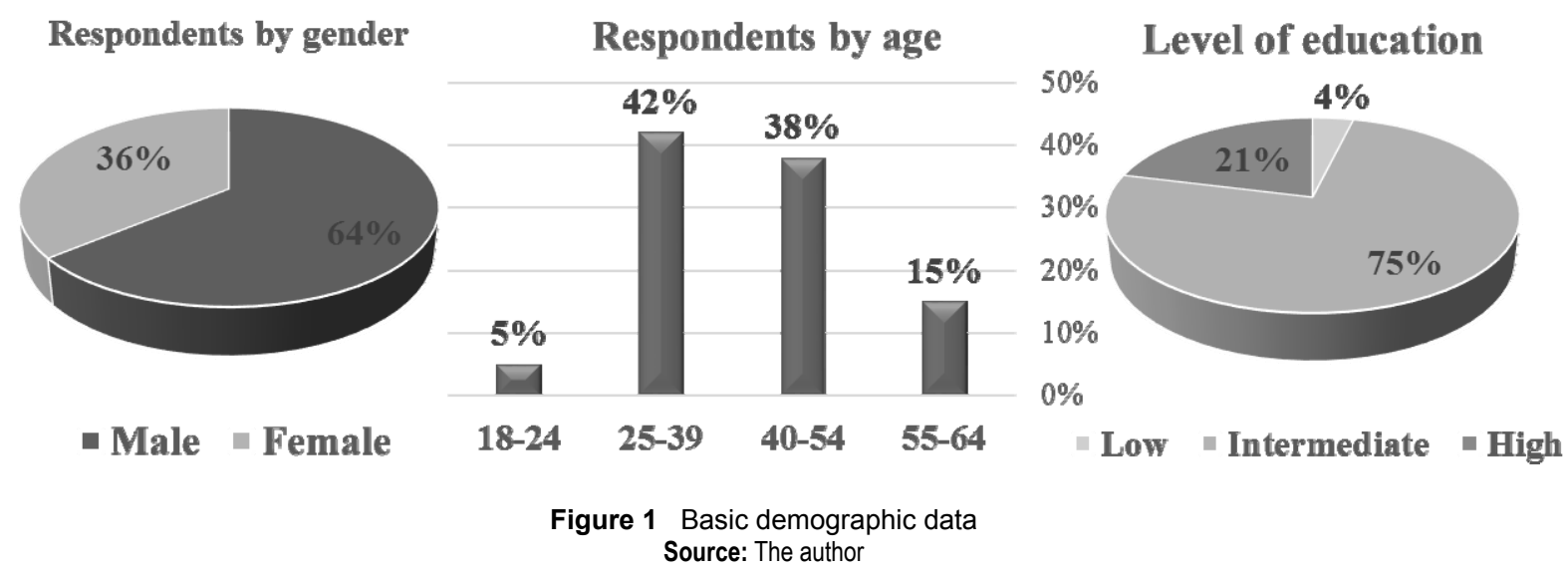

$94 \%$ of the surveyed people are full-time employees. In terms of the sector, most work in the following five categories: manufactured products; other services; wholesale and retail trade services, repair services of motor vehicles and motorcycles; Constructions and constructions works and Information and communication services. The following figure contains additional basic information about the workplace.

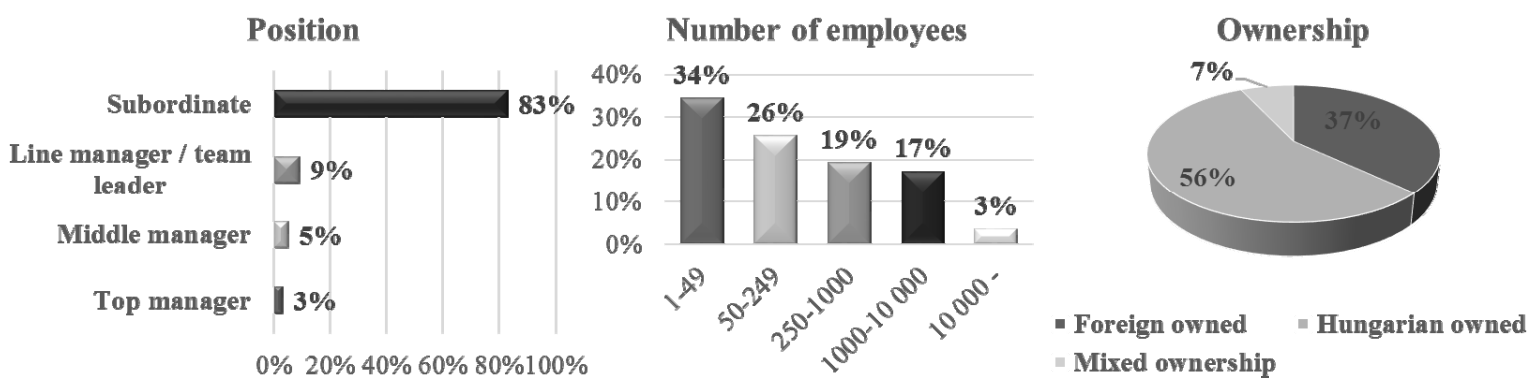

Figure 2 Basic information about the workplace Source: The author

The majority of respondents work as subordinates $(83 \%)$. Most of them are employees of small and medium-sized enterprises $(60 \%)$. More than the half $(56 \%)$ of employers have Hungarian owners.

After presenting the basic features of the sample, questions relevant to the topic of the study will be evaluated in the next subchapter.

\section{Results of the research}

\subsection{Organizational career management from the employee's perspective}

In this subchapter results related to organizational career management practice are presented, which were surveyed from the perspective of employees. The respondents had to indicate how many times applied each of the listed career management solutions in the last year. After filtering out the outliers, the table below shows the number of times the tool was used by employees, and the number of workers who used the technique as a whole, and the average usage rate among employees. A total of 18 career development solutions were surveyed and it was also possible for the respondents to mark other options.

\subsubsection{Frequency of career management tools' application}

According to results (see in Table 1), the most frequently applied tool is special work tasks, respondents used it 4626 times, totally 440 participants performed this task, which is $44 \%$ of all respondents. In other words, 440 employees have participated in this career development solution a total of 4626 times. If we compare the frequency of use with the people who benefited from this solution, on average, one person did a special job ten times (the average: 10.51) last year.

Very common techniques were also project work (2928), networking opportunities (2045), 
training opportunities (1707) and performance appraisal as a basis for career planning (1425), as well as mentoring and coaching (1388). Approximately one third of the respondents used these solutions, except for training opportunities, where this ratio reaches $39 \%$, making it the second most popular technique in terms of the proportion of users. In addition, only a fifth of the respondents $(20 \%)$ could participate in mentoring and coaching, but they often did it in the last year, as shown by the average use indicator (6.9).

Table 1 Frequency of career management tools' application

\begin{tabular}{l|l|l|l|l|l}
\hline \multicolumn{2}{l}{ Career management tool } & $\begin{array}{l}\text { Number of } \\
\text { usage }\end{array}$ & $\begin{array}{l}\text { Number of } \\
\text { users }\end{array}$ & $\begin{array}{l}\text { Portion of } \\
\text { users (\%) }\end{array}$ & $\begin{array}{l}\text { Average usage per user } \\
\text { (occasion/ person) }\end{array}$ \\
\hline 1. & Special tasks & 4626 & 440 & $44 \%$ & 10,51 \\
\hline 2. & Project work & 2928 & 316 & $32 \%$ & 9,27 \\
\hline 3. & Networking opportunities & 2045 & 298 & $30 \%$ & 6,86 \\
\hline 4. & Training opportunities & 1707 & 394 & $39 \%$ & 4,33 \\
\hline 5. & $\begin{array}{l}\text { Performance appraisal as a basis for } \\
\text { career planning }\end{array}$ & 1425 & 279 & $28 \%$ & 5,11 \\
\hline 6. & Mentoring, coaching & 1388 & 201 & $20 \%$ & 6,9 \\
\hline 7. & Projects to stimulate learning & 1317 & 250 & $25 \%$ & 5,27 \\
\hline 8. & $\begin{array}{l}\text { Career workshops, information } \\
\text { materials }\end{array}$ & 1289 & 179 & $18 \%$ & 7,2 \\
\hline 9. & Computer based packages/ e-learning & 1250 & 251 & $25 \%$ & 4,98 \\
\hline 10. & Career counselling & 878 & 162 & $16 \%$ & 5,42 \\
\hline 11. & Job rotation & 694 & 179 & $18 \%$ & 3,88 \\
\hline 12. & Lateral movement in the organization & 567 & 101 & $10 \%$ & 5,61 \\
\hline 13. & Talent program & 538 & 98 & $10 \%$ & 5,49 \\
\hline 14. & Promotion, succession planning & 451 & 198 & $20 \%$ & 2,28 \\
\hline 15. & Development centre & 413 & 61 & $6 \%$ & 6,77 \\
\hline 16. & Career plan & 338 & 129 & $13 \%$ & 2,62 \\
\hline 17. & International work assignments & 324 & 116 & $12 \%$ & 2,8 \\
\hline 18. & Retirement preparation program & 158 & 71 & $7 \%$ & 2,23 \\
\hline
\end{tabular}

Practices supporting career development are in the middle of the list such as projects to stimulate learning (1317), career workshops and information materials (1289), computer based packages / e-learning (1250), career counselling (878), job rotation (694), lateral movement in the organization (567) and talent program (538). Among the above listed tools projects to stimulate learning and computer based packages / elearning solutions are used by the majority of respondents $(25 \%)$, the fourth. Almost a fifth of respondents participated in career workshops, received career information material $(18 \%)$ or was involved in job rotation (18\%) in the last year.

The least applied career solutions are at the end of the list like promotion, succession planning (451), development centre (413), career plan (338), international work assignments (324) or retirement preparation programs (158). One fifth of the respondents $(20 \%)$ were promoted. $13 \%$ had a career plan and $12 \%$ took part in international assignment. Among the recipients of career support solutions, the least were involved in development centre $(6 \%)$ or retirement preparation program (7\%). It is interesting that considering all the tools, the average use is the second lowest in the case of promotions (2.28), which means that although more people have been promoted, this happened twice on average. This is not surprising considering the flatter organizational structures and limited advancement opportunities. It is also interesting that, although only $6 \%$ of the respondents were part of the development centre, but they often participated in this solution (6.21). The age distribution of participants in retirement preparation programs $(7 \%)$ is quite variable, not necessarily only the older colleagues are involved in it. Only $11 \%$ of 54-year-olds participated in such a program.

Overall, it can be seen that the surveyed career management tools were used by a maximum of $44 \%$ of the respondents. The number of occasions, how often they were used, varies between two and ten by users. Which means that the application of some solutions is more common for one person, while others is lower, which may depend on how simple, costly, time-consuming, energy-intensive or efficient the usage of a particular solution is. 


\subsubsection{Effectiveness of career management tools}

In terms of efficiency, the results are shown in the following table.

Table 2 Effectiveness of career management tools

\begin{tabular}{l|l|l|l|l}
\hline \multicolumn{2}{l}{ Career management tool } & Usefulness* & Portion of users (\%) & Usage ranking \\
\hline 1. & Training opportunities & 4,34 & $39 \%$ & 4. \\
\hline 2. & Projects to stimulate learning & 4,12 & $25 \%$ & 7. \\
\hline 3. & Networking opportunities & 4,07 & $30 \%$ & 3. \\
\hline 4. & Special tasks & 4,06 & $44 \%$ & 1. \\
\hline 5. & Promotion, succession planning & 4,02 & $20 \%$ & 14. \\
\hline 6. & Computer based packages/e-learning & 3,98 & $25 \%$ & 9. \\
\hline 7. & Project work & 3,92 & $32 \%$ & 2. \\
\hline 8. & Development centre & 3,91 & $6 \%$ & 15. \\
\hline 9. & Talent program & 3,90 & $10 \%$ & 13. \\
\hline 10. & International work assignments & 3,86 & $12 \%$ & 17. \\
\hline 11. & Mentoring, coaching & 3,86 & $20 \%$ & 6. \\
\hline 12. & Performance appraisal as a basis for career planning & 3,86 & $28 \%$ & 5. \\
\hline 13. & Retirement preparation program & 3,75 & $7 \%$ & 18. \\
\hline 14. & Career counselling & 3,72 & $16 \%$ & 10. \\
\hline 15. & Career workshops, information materials & 3,67 & $18 \%$ & 8. \\
\hline 16. & Career plan & 3,67 & $13 \%$ & 16. \\
\hline 17. & Job rotation & 3,62 & $18 \%$ & 11. \\
\hline 18. & Lateral movement in the organization & 3,57 & $10 \%$ & 12. \\
\hline
\end{tabular}

The respondents had to evaluate each career practice on a scale of 1 to 5 , to see how useful they were to promote their careers. All career management solutions were rated as useful by the respondents on average. Training opportunities were rated by employees as the most useful tool (an average of 4.34), which is the 4th most commonly used career management instrument as shown in the previous table. The first five most useful techniques include also the followings: projects to stimulate learning (4.12), networking opportunities (4.07), special tasks (4.06) and promotion, succession planning (4.02). Among them, training opportunities and special tasks were available to many $(39 \%$ and $44 \%$ of respondents), as could be seen previously in the proportion of users. Interestingly, the promotional practice was rated the 5 th most valuable technique by the respondents, although few benefitted from it or rarely applied by employers, as it was described before. This may also be explained by the fact that many see the possibility to develop their careers in upward movement in the hierarchy, but it is given to a few workers due to the reasons already mentioned.

There are career development solutions in the middle of the list that were ranked ahead in terms of frequency of use as could be seen in the previous table, such as project work (3.92), mentoring and coaching (3.86) and performance appraisal as a basis for career planning. Also, there are tools in the middle field that were listed at the end of the frequency ranking, such as development centre (3.91), talent program (3.90), or international work assignments (3.86), which may also indicate that organizations could use these solutions more often.

In the last third of the list, there are career management techniques that reach less than a fifth of employees and regarding the frequency of use, they are in the middle or at the end of the frequency table. There is an exception, career workshops and information materials, which are measured as the 8th most used tool.

\subsubsection{Career opportunities in the workplace}

The following figure presents the degree of information the employees have in connection with their career opportunities. The majority of employees think that they are relatively well informed about their career opportunities at work $(21 \%+16 \%)$. One third of them see $(33 \%)$ that they have only partial information, while slightly less than one third $(30 \%)$ are less or not notified at all. On average, respondents were partially informed (3.08). 


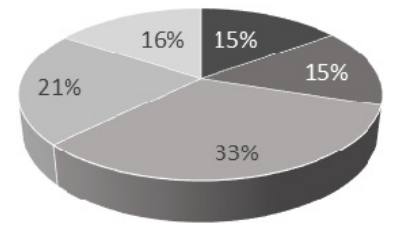

- 1- I am not informed at all $=2$ - I am rather not informed

- 3 - I am partially informed $\| 4$ - I am rather informed

- 5 - I am fully informed

Figure 3 Evaluating career information at the workplace $(\mathrm{N}=1000)$

Source: The author

The respondents had to evaluate their career opportunities on a scale of 1 to 5 in their workplace. The results are shown in the diagram below.

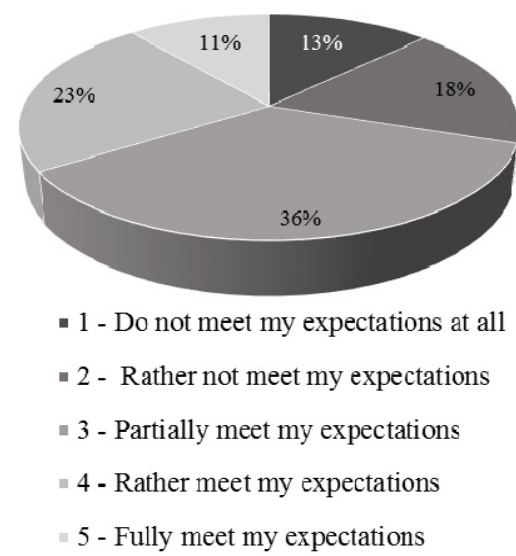

Figure 4 Evaluating career opportunities at the workplace $(N=1000)$ Source: The author
The majority $(36 \%)$ partly considered their career options to be in line with their expectations. One third of respondents are less or not at all satisfied with their opportunities, while another third of them evaluate the alternatives as more or fully acceptable. On average, career prospects partly meet the expectations of the respondents (3.03).

According to cross-table analysis, you can see that those who are more informed about their career prospects evaluate their career opportunities at least as medium or better. While those who are less or not at all informed, they consider their career options to be medium or worse. Chi-square test confirmed that there is a correlation between evaluation of information and career opportunities, consequently employers should pay more attention to informing their employees.

\subsubsection{Expected and received career support}

Finally, the expected and actual career supports were evaluated. $53 \%$ of the workers would expect help in developing their careers, but only $21 \%$ of them actually get support. The respondents had to distribute exactly 100 points between the various actors, depending on the degree of support they expect to advance their careers, and actually how much help they actually receive. The results are shown in the figure below.

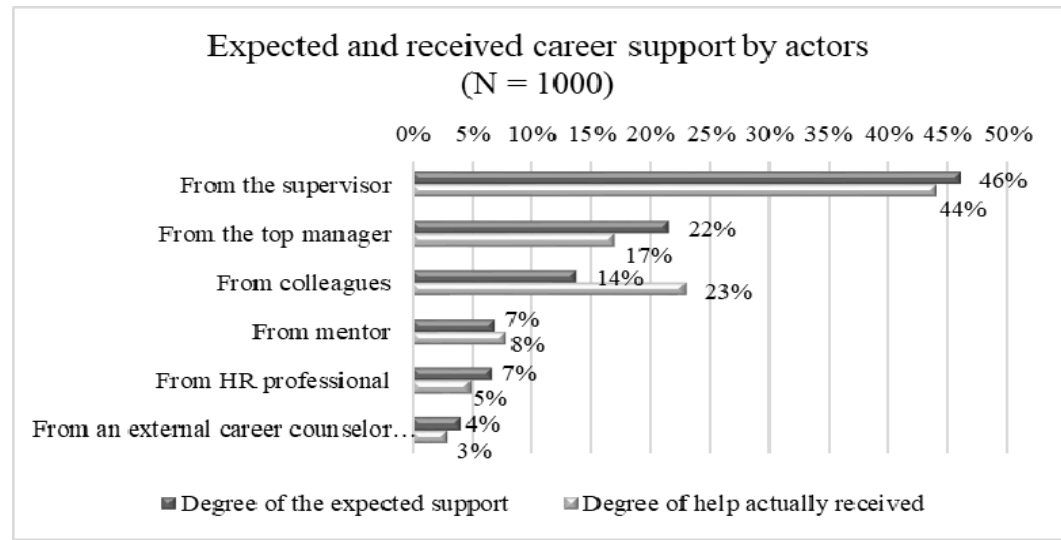

Figure 5 Expected and received career support by actors $(N=1000)$ Source: The author

In the case of managers (direct and top) and HR colleagues, it can be seen that some more help
(46\%; 22\%; and 7\%) would be expected for employees than they actually receive $(44 \% ; 17 \%$ 
and 5\%). Support from colleagues is also significant $(23 \%)$, but respondents would require fewer (14\%). They would probably expect more assistance from the three character mentioned above. Mentors should also play a somewhat smaller role $(7 \%)$ than they have now $(8 \%)$. Overall, it is found that employees receive support mostly from those to manage their career from whom they expect, but in some cases, such as managers and HR colleagues, workers would require a little more assistance. The participants would like to get some help even from outside experts $(4 \%)$.

\section{Limitations}

As for the answers, it should be noted that this is the assessment and opinion of the employees. It reflects their own experiences and knowledge, so the results should be treated and interpreted accordingly. It is possible that respondents may have participated in other career management solutions than they selected, or more often or less often. In addition, they may find a technique to be less useful but actually it may be an effective practice. The lower rating may be due to their poor knowledge or even their bad experience with the tool. The judgment of career prospects or received career support can be very subjective, too, but it is worth considering the opinions, because the employees think and act on the basis of them. Therefore, if employers find the assessment of the employees correct, they should apply the relevant career solution more often. If they think it is incorrect then they should inform their workers better about the content, benefits and potential drawbacks of each technique so that the employees get a more realistic picture of career tools. All in all, the results can be considered useful feedback for managers or HR professionals.

\section{Summary and conclusion}

The most frequently applied tools in Hungary are special work tasks, project work, networking opportunities, training opportunities and performance appraisal as a basis for career planning, as well as mentoring and coaching. The most often used career management solutions are applied mostly by the most employees therefore we can conclude that these are the most popular career interventions. These results are in line what earlier was mentioned in the literature part of the study. These tools can be considered as rather supportive and developer technics. Furthermore they show similarities with the results of previous researches as can be seen in the following table.

Table 3 Most common career management tools in previous and present research

\begin{tabular}{l|l}
\hline \multicolumn{2}{c}{ Most common career management solutions } \\
\hline According to earlier studies & According to the empirical research \\
\hline special assignments & special work tasks \\
\hline project work & project work \\
\hline internal job opening practices & networking opportunities \\
\hline training-development solutions & training opportunities \\
\hline performance appraisal as part of career development & performance appraisal as a basis for career planning \\
\hline career consulting & mentoring and coaching \\
\hline
\end{tabular}

Overall, it can be seen that the surveyed career management tools were used by a maximum of $44 \%$ of the respondents. The number of occasions, how often they were used, varies between two and ten by users, which means that the application of some solutions is more common for one person, while others is lower, which may depend on how simple, costly, time-consuming, energy-intensive or efficient the usage of a particular solution is.

All career management solutions were rated as useful by the respondents on average. However, the efficiency order set by respondents is different from the frequency of use. Career management tools that are evaluated most effective by employees are the following: training opportunities, projects to stimulate learning, networking opportunities, special tasks and promotion, succession planning.

On average, respondents were partially informed and career prospects partly meet their expectations. All in all those who are more informed about their career prospects evaluate their career opportunities rather better. While those who are less or not at all informed, they consider their career options to be rather worse. Consequently employers should pay more 
attention to informing their employees. As for career support, majority of the workers would expect help in developing their careers, but only few of them actually get support. It is found that employees receive support mostly from those to manage their career from whom they expect, but in some cases, such as managers and HR colleagues, workers would require a little more assistance.

In conclusion, employers should consider applying certain career management tools more often as they do or they should involve in it more workers. For more effective cooperation, it would be worth to inform better their employees about career opportunities and give them more career support because they would require it.sm

\section{References}

Baruch, Y. (2008). Fostering career development in organizations. In: Burke, R. J. - Cooper, C. L. (Eds.), The Peak Performing Organization (pp. 92-107), Routledge. https://doi.org/10.4324/9780203971611.ch5

Baruch, Y. (2003). Career systems in transition: A normative model for career practices. Personnel Review, 32 (2), 231-251. https://doi.org/10.1108/00483480310460234

Baruch, Y., \& Peiperl, M. (2000). Career management practices: An empirical survey and implications. Human Resource Management, 39 (4), 347-366. https://doi.org/10.1002/1099050X(200024)39:4<347::AID-HRM6>3.0.CO;2-C

Berber, N., \& Slavic, A. (2014). The practice of career development in the international human resource management of the European countries. Journal of Engineering Management and Competitiveness (Jemc), 4 (1), 21-26. https://doi.org/10.5937/jemc1401021B

Bernes, K., \& Magnusson, K. (1996). A description of career development services within Canadian organizations. Journal of Counseling and Development, 74 (6), 569574.

https://doi.org/10.1002/j.1556-6676.1996.tb02294.x

Budhwar, P.S, \& Baruch, Y. (2003). Career management practices in India: an empirical study. International Journal of Manpower, 21 (6), 699- 719. https://doi.org/10.1108/01437720310496166

Creed, P., \& Hood, M. (2009). Career development, planning and management from the organisational perspective. In: Collin, A. - Patton, W. (Eds.), Vocational psychological and organisational perspectives on career: Towards a multidisciplinary dialogue (pp. 41-62). Rotterdam, The Netherlands: Sense Publications. https://doi.org/10.1163/9789087909178 005

Clarke, M. (2013). The organizational career: not dead but in need of redefinition. The International Journal of Human Resource Management, 24(4), 684-703. https://doi.org/10.1080/09585192.2012.697475
De Vos, A., \& Cambré, B. (2017). Career Management in High-Performing Organizations: A Set-Theoretic Approach. Human Resource Management, 56(3), 501518. https://doi.org/10.1002/hrm.21786

Drugău-Constantin, A. (2018). Non-Employment Work Arrangements in Digital Labor Marketplaces: Who's Fooling Who? Journal of Self-Governance and Management Economics, 6 (3), 136-142. https://doi.org/10.22381/JSME6320185

Gottfredson, G.D. (2005). Career development in organizations. In W. B. Walsh, \& M. L. Savickas (Eds.), Handbook of vocational psychology: Theory, research and practice (pp. 297-317). Mahwah, NJ: Lawrence Erlbaum.

Hamori, M., Bonet, R., \& Cappelli, P. (2011). How Organizations Obtain the Human Capital they Need. Oxford University Press.

https://doi.org/10.1093/oxfordhb/9780199532162.003.0 $\underline{013}$

Hall, D. T., \& Associates (1986). Career development in organisations. San Francisco, CA: Jossey-Bass.

Koncz K. (2013). A sikeres szervezeti karrierfejlesztés feltételei. Munkaügyi Szemle, 57 (4), 32-43.

Koncz K. (2002). Életpálya és munkahelyi karriermenedzsment. Vezetéstudomány, 33 (4), 2-14.

László, G., Sipos, N., \& Slavić, A. (2018). The role of trade unions in the HRM of Hungarian and Serbian organizations. Anali Ekonomskog fakulteta u Subotici, (40), 67-79. https://doi.org/10.5937/AnEkSub1840067L

Leibowitz, Z. B., Farren, C., \& Kaye, B. L. (1986). Designing career development systems. San Francisco, CA: Jossey-Bass Publishers.

Lewis, S., \& Arnold, J. (2012). Organisational career management in the UK retail buying and merchandising community. International Journal of Retail \& Distribution Management, 40 (6), 451- 470. https://doi.org/10.1108/09590551211230269

Madagamage, G.T, Perera, G.D.N, \& Thalgaspitiya, U.K (2018). Career Management Practices in Sri Lanka: An Empirical Investigation. International Journal of Marketing and Human Resource Management, 9 (2), 9 17. https://doi.org/10.34218/IJMHRM.9.2.2018.002

Mitea, D. R. E. (2018). The Expansion of Digitally Mediated Labor: Platform-Based Economy, Technology-Driven Shifts in Employment, and the Novel Modes of Service Work. Journal of Self-Governance and Management Economics, 6 (4), 7-13. https://doi.org/10.22381/JSME6420181

Nica, E. (2018). Gig-based Working Arrangements: Business Patterns, Labor-Management Practices, and Regulations. Economics, Management, and Financial Markets, 13 (1), 100-105. https://doi.org/10.22381/EMFM13120185

Szabó, Sz., Slavić, A. \& Berber, N. (2019). Coaching and its effects on individual and organizational performances in Central and Eastern Europe. Anali Ekonomskog fakulteta u Subotici, (41), 67-80. https://doi.org/10.5937/AnEkSub1941067S 


\section{$\square$ Correspondence}

\section{Brigitta Szabó-Bálint}

University of Pécs, Faculty of Business and Economics, Pécs

80 Rákóczi street, H-7624 Pécs, Hungary

E-mail: balintb@ktk.pte.hu 